\title{
WORKPLACE CONFLICT \\ MANAGEMENT: LEGAL \\ INTENTIONS VERSUS MANAGERS' EXPERIENCES
}

\author{
Gaye Greenwood \& Erling Rasmussen
}

\author{
AUT Business School, Auckland University of \\ Technology
}

\begin{abstract}
The Employment Relations Act 2000 directs employees and employers to resolve employment relationship problems (ERP'S) early without judicial intervention. The goal is to 'build mutual trust and confidence in all aspects of the employment environment'. However, the policy intentions to focus on early resolution through problem solving, interest based negotiation, facilitation and mediation have not been researched at the level of the workplace. Drawing on conflict events in the primary school sector this paper investigates the theme of relational trust. The preliminary findings reported in this paper have emerged from a qualitative study that involved semi-structured interviews with a range of actors. A preliminary analysis identified situations where parties had resolved problems without damaging trust by implementing reflective collaborative interest based processes. In spite of identifying positive outcomes of conflict events, principals and senior leaders reported that trust was damaged when competition for performance based remuneration fuelled conflict and when complaints from parents escalated. These findings highlighted the special nature of conflict management in schools where the goal of 'mutual trust and confidence in all aspects of the employment environment' may be vulnerable to complex conflicts of interest in the employment relationship in the New Zealand primary education sector.
\end{abstract}

\section{Introduction}

Over the last decade New Zealand research about the employment relations problem resolution system has focussed on the state-created employment institutions, structures and processes for collective bargaining, rates of grievance handling, the relationship between unions and employers, union density and conflict escalation. It has been identified in academic literature (McAndrew, 2010; Walker \& Hamilton, 2010) and state commissioned research (McDermott Miller, 2007; Woodhams, 2007) that there is a lack of understanding about early resolution of employment relationship problems.

While high or low numbers of disputes and grievances in the institutional setting have been applied as indicators of workplace conflict in previous literature (Department of Labour 2002a, 2002b; Waldegrave, Anderson \& Wong, 2003), little is known about employment relationship problems (ERP's) that have been settled through the free (state funded) mediation service or resolved at the level of the workplace. Walker and Hamilton (2010) confirmed the need for in-depth analysis of conflict management within organisations because survey based research and satisfaction surveys painted an incomplete picture. Conducting case study research on mediation, Walker and Hamilton (2010) also concluded that investigation of the organisation's culture, values and ways of operating would have provided a deeper understanding of grievances and disputes.
However, there is an international lack of empirical data that evaluates the efficacy of dispute resolution processes for employees, employers or organisations. The costs and benefits of employer/employee problem and dispute resolution have not been fully explored (Shulruf et. al., 2009). Importantly, there is a significant gap in empirical research about conflict management in the New Zealand workplace. Innovative early conflict resolution processes, such as good faith negotiation and early assistance mediation, have been enshrined in legislation for over a decade but have yet to be the subject of in-depth academic inquiry.

This paper begins by outlining the background to conflict management in New Zealand with a focus on the duty to act in good faith. The second section of the paper briefly reviews international conflict management literature and the third section outlines the methodological approach to the research. The fourth section discusses the significance of relational trust in education and identifies the reported success of a reflective problem solving approach taken by a team leader compared with a settlement approach taken by a Board of Trustees. It also highlights unresolved problems both for teachers and schools when conflict is managed by financial settlement, rather than resolving underlying interests during confidential mediation or negotiation.Gender and trade union renewal 


\section{Background}

The Employment Relations Act 2000 signalled a fundamental ideological shift: from the former neoliberal, 'free market' transaction between the employer and employee of the Employment Contracts Act 1991 to a relational approach, one of social exchange. The policy goal was to view the employment agreement as more than a contract of service. The employment 'agreement' acknowledged the human relationship where people contributed effort and participation in return for formal and informal reward. The Act required both employers and employees to act in good faith during their day-to-day interactions to build relational trust. The obligation of good faith communication at the level of the workplace was an attempt to influence behaviour during negotiation, normalise conflict and embed open communication during the bargaining of wages, conditions and processes for the management of conflict.

The explicit requirement for good faith behaviour in the ERA 2000 is defined by the Department of Labour to include the duty to:

- act honestly, openly, and without hidden or ulterior motives

- $\quad$ raise issues in a fair and timely way

- $\quad$ be constructive and cooperative

- be proactive in providing each other with relevant information and consider all information provided

- $\quad$ respond promptly and thoroughly to reasonable requests and concerns

- $\quad$ keep an open mind, listen to each other and be prepared to change opinion about a particular situation or behaviour, and

- $\quad$ treat each other respectfully.

http://www.dol.govt.nz/er/solvingproblems/keyprinciples/ goodfaith.asp

The objective to enhance trust and normalise inevitable conflict in the employment relationship through the requirement for good faith behaviour was reinforced by the language of the legislation. The term employment relationship problem (ERP) was a neutral framing of workplace conflict and signposted a move to a collaborative problem solving approach to dispute resolution. "ERP's were no longer to be defined by reference to the legal causes of action; it was possible to resolve employment relationship conflict before it was defined legally or escalated to a dispute” (Public Policy Academic in Greenwood, 2013). Workplace conflict management processes were to be supported by the 'fast, free and fair' mediation service (Wilson, 2000), funded by the state which aimed to reduce the need for litigation. The free provision of negotiation education and information through a state funded call centre aimed to enhance productivity by resolving ERP's early, thereby strengthening joint commitment to an on-going relationship. The legislation stated the innovative goals of building relational trust through good faith behaviour and problem solving relational conflict in its object thus:

"(a) to build productive relationships through the promotion of mutual trust and confidence in all aspects of the employment environment and of the employment relationship -

(i) by recognising that employment relationships must be built on good faith behaviour; and

(ii) by acknowledging and addressing the inherent inequality of bargaining power in employment relations; and

(iii) By protecting the integrity of individual choice; and

(iv) By promoting mediation as the primary problemsolving mechanism; and

(v) By reducing the need for judicial intervention, and

(b) to promote observance in New Zealand of the principles underlying International Labour Organisation Convention 87 on Freedom of Association, and Convention 98 on the Right to Organise and Bargaining Collective.” (Section 3, ERA 2000).

\section{International conflict management}

The efficacy of individual access to early conflict management processes concurrent with collective bargaining as reflected in the dual objectives of the Employment Relations Act 2000 is internationally debated. The key issue is whether individualised informal interest based processes disempower unions (Stone, 2002; Lipsky \& Seber, 2003). According to Rousseau (2004), there is pressure on management to engage in innovative conflict management practices to strengthen relational psychological contracts. The psychological contract is 'an individual's belief in mutual obligations between that person and another party such as between the employee and the employer' (Rosuseau \& Tijoriwala, 1998: 679). The term is applied to explain the implicit or taken for granted assumptions about appropriate conduct in the workplace (Rousseau, 1995; Guest, 2004). The nature of the psychological contract can influence, therefore, levels of trust in the employment relationship. Here it is opined that the ERA 2000 requirement for good faith behaviour aimed to provide a legislative framework for building trust through open communication and a problem solving approach to the management of workplace conflict However, international researchers have been less optimistic about the intentions of individualised interest based conflict management processes.

Osterman (1994) claimed that high performance workplaces supported competitive strategies focussed on innovation and quality, and, thus, organisations were diffusing new conflict management policies to remain competitive. While Colvin (2003) had reported individualised innovative conflict management practices in non-union workplaces enjoyed the support of employees, both Lewin (2004) and Roache and Teague 
(2011) identified a lack of trust in mutual gains approaches to individualism in employment negotiation and innovative alternative dispute resolution (ADR) processes. ADR referred to processes which mirrored the New Zealand institutional provision of communication and conflict coaching, mutual interest based negotiation, mediation and arbitration which provide alternatives to traditional adversarial litigation. Roche and Teague, (2011) concluded that individualism and labour market changes had pulled systems in different directions with a lack of data to provide adequate understanding of how the individualised innovative ADR and traditional collective approaches would co-exist and serve employees in the future. Lewin (2004) reported that non-union firms adopted a battery of conflict management policies so that employees felt their needs and interests were being catered for by the firm. Whether the aim was to strengthen affective commitment and relational trust in the psychological contract between the organisation and employee and/or respond to the diversity in the workplace has been unclear. So far, research has focused on the growth in individualised ADR, the reduction in union density and whether or not interest based processes posed a threat to union bargaining power.

In short, there is a gap in research about the informal management of individual conflict events in the workplace. This could be explained by both design and ethical issues for researchers who seek to investigate workplace conflict. Consultation with all parties to a conflict and triangulation of data could be harmful to the parties and the organisation. Simulated experimental research design cannot replicate spontaneous communication events to provide in-depth understanding of participants' experiences. Survey research has focused on comparative research about union and non-union workplace grievance procedures, conflict management systems and interest based ADR practices compared with traditional formal stepped or positional bargaining procedures that involved written negotiations of complaints, competency and disciplinary matters (Lewin, 1987, 1999; Fueille, Chatchere \& Delaney, 1992; Lipsky \& Seber, 2003; Colvin, 2003; Cutcher-Gershenfeld et. al., 2007; Roche \& Teague, 2011).

Other streams of literature focussed on circumstances under which processes such as mediation and arbitration in collective bargaining should be implemented (Dunlop \& Zac 1997; Ury, Brett \& Goldberg, 1989), or negotiation (Lewicki, Saunders \& Minton, 2000; Fisher \& Ury, 1999; Walton, Cutcher-Gershenfeld \& McKersie, 2000). In the 1980’s, Ury, Brett and Goldberg (1988) warned that the organisational context shaped the way conflict was managed. Ostrom (2006) noted that researchers had still not researched mediation styles in institutional contexts. A significant body of empirical work has followed the mediation of disputes in the US postal service REDRESS (Bingham, 1997; Bingham et. al., 2000; Bingham \& Novac, 2001; Bingham \& Pitts, 2002; Bingham, 2012). There have been common questions throughout the literature concerned with what types of conflict manifest in individualised non-union or unionised workplaces, and under what conditions firms implemented individualised or collective systems. Roche and Teague (2011) questioned whether there was a link between what they defined as innovative conflict management systems, the rise in individualism and high performance management. They surveyed firms in Ireland categorising innovative ADR conflict management practices as

- external arbitration

- engagement of external experts as early as possible to assist

- early brainstorming and problem solving to resolve problems

- $\quad$ use of formal interest based win/win negotiation techniques

- intensive formal communications regarding change and consultation as ADR practice to prevent conflict.

Apart from the absence of access to a free state-sponsored mediation service and the continued use of arbitration, the procedures above reflect the ADR processes embedded in the innovative New Zealand legislation. Roche and Teague (2011: 454) asserted the innovative ADR conflict management practices "reflected a broad based attempt to foster commitment by aligning non-adversarial and consensus focussed approaches to dealing with disputes or contentious issues”. Colvin (2004) had identified a relationship between team based working conditions and innovative conflict management practices and Lipsky and Seber (2003) had asserted high performance workplaces had driven innovative ADR conflict management practices. The aim of the New Zealand legislation was to facilitate collaborative processes that were asserted to enhance productivity and prevent dispute escalation.

Claims of positive change in communication and the employment relationship when there was increased early ADR intervention has been common in professional ADR practitioner literature (Cloke, 2006; Cloke \& Goldsmith, 2000; Tillet \& French, 2009; Bush \& Folger, 2005; Bowling \& Hoffman, 2003; Winslade \& Monk, 2008). There has also been increasing awareness of the value of designing specific workplace dispute systems (Ury, Brett \& Goldberg, 1989; Constantino and Merchant, 1996; Donais, 2006; Bingham, 2012). However, systems, policies and processes for the early resolution of workplace conflict have proven difficult to compare or evaluate. Researchers (Felstiner, Abel \& Sarat, 1981; Bingham \& Chatechere, 1999; Antes, Folger \& Della Noce, 2001; Bingham, 2004), and mediators (Mayer, 2004; Bush \& Folger, 2005) have articulated the gap in international research about the phases of emergence, transformation, resolution, settlement, or escalation from problems to conflict, grievance and dispute. There has been a response to calls for empirical research that identifies dimensions for comparing early conflict resolution processes such as interest based negotiation (Mayer 2004; Budd \& Colvin, 2008) and transformative mediation (Bingham \& Chatechere, 1999; Bingham, 2004). Bingham (2012) found that transformative processes were effective for fostering perceptions of interpersonal justice between disputants and that there was a need for more research on styles of mediation. 
International comparative research has been hindered by differences between internal and external dispute resolution systems and those delivered through the private and public sectors as well as across federal or nation states and different legal and policy contexts (Walker, 2009; Bingham, 2004; Donais, 2006; Bingham \& Cachere, 1999; Feuille \& Delaney, 1992). Roche and Teague (2011) noted research on conflict management systems had predominantly focused on internal systems design in large organisations (Bingham, 2004: Jameson, 2000; McDermott, 1995; Ewing, 1989; McCabe 1988; Lewin, 1987). One dispute system design that has been extensively evaluated and reported by Bingham (2012) found that organisational context shaped how disputants responded to perceptions of justice in the REDRESS transformative mediation process. That service was contracted out to independent contract mediators to the US postal service for individual discrimination complaints in a highly unionised environment.

The research reported in this paper is concerned with internal conflict management in the context of schools where conflict may involve individuals in a union environment. The research conceptualised workplace conflict as defined by Roche and Teague (2011: 442):

Workplace conflict involves differences of view and conflict between individual employees and their employer; among individuals; and between groups of employees, whether unionised or not, and their employer. It is recognised that the management of workplace conflict can have beneficial effects for employers, employees and other stakeholders in the business.

\section{Methodology}

A social constructivist approach was taken in this qualitative research because the study aimed to understand and describe how participants made meaning of conflict events according to differing values and world views (Guba \& Lincoln, 1994; Cooperrider \& Barrett, 1990; Crotty, 2003; Cresswell \& Plano-Clark, 2006; King \& Horrocks, 2010). Studying the emergence and transformation of conflict events required studying the social process in which they occurred (Felstiner, Abel \& Sarat, 1981). Relational problems, conflicts, and disputes are social constructs, stories with differing perspectives, negotiation strategies and styles of communication between individuals and groups. In the education, sector the interplay between pedagogical beliefs (theories of thinking, learning and teaching) alongside the negotiation of workplace relationships suggested that philosophical tensions and relational conflict could be common place.

Specifically, the purpose of this study was to discover how leaders, principals and boards of trustees understood and managed conflict and ERP's in primary school workplaces. This begged the question of whether conflict events were constructed or conceptualised as opportunities for learning which could have beneficial effects or, on the other hand, considered negative, destructive events that damaged trust in relationships. Overall, we sought to discover how the aims of mutual trust, good faith behaviour, problem solving and mediation embedded in New Zealand employment law and public policy were understood and applied to employment relationships in primary schools.

\section{Research methods}

Qualitative insights about conflict management were gained from semi-structured, in-depth interviews with 7 principals, 6 deputy or associate principals, 9 mediators, 7 past or present members of Boards of Trustees, 11 legal experts in education and/or employment dispute resolution and 4 participants who had influenced policy as representatives of interest groups. The units of analysis were conflict events and there have been in excess of 200 conflict events reported during the participants' interviews. The narratives included self-reported experiences, insights into employment relationship problems and conflict management strategies, reflection on events, relationships, interests and issues, negotiation and conflict resolution processes with commentary on relational trust. Research questions included how and why problems were resolved or not resolved, how and why they were settled, and how and why relationships were transformed or severed. At appropriate intervals during or following participants' narratives, reflection on learning from the incidents was encouraged.

The interviews were digitally recorded and transcribed. Qualitative data from interviews is currently being coded and thematically analysed using Nvivo 9 Software. However, the data analysis required detailed accounts of context specific information about school settings, processes, policies, communications and relationships within schools and from which participants interpreted events and experiences. Therefore, more than 200 relational conflict events are being tabulated by typology, issues and interests, relationships, personal characteristics, procedures, background, outcomes, policy, practice and impact on trust. A comparison between reported policies, process and practice is being made. A thematic analysis of the transcriptions is currently being undertaken and for the purpose of this paper one emergent theme is reported. That theme is relational trust.

Ethical considerations have included the safety of participants when gaining access to schools and conducting interviews with members of boards of trustees, principals and senior management teams by snowball sampling. Teachers, who were party to conflict events, were not interviewed because there was a potential risk of escalating conflict and subsequent harm when conducting interviews given the power imbalance between employer and employees. Thus, one limitation of the research is that it reports only the management and governance perspectives on relational conflict in the primary school workplace.

The participants in the research either self-identified at professional development training or seminars following a presentation by the researcher or were referred by colleagues from those presentations. On three occasions, potential participants approached the researcher stating they were motivated to tell their story but sought the 
researcher's advice on confidentiality as they had not retained their jobs as school principals following mediation. They were unable to be included in the research.

Finally, a contextual limitation of the research is the range of socio economic groups represented in the data. The interviews were with principals and deputy principals/associates, team leaders from seven schools from three decile 10, two decile 9, one decile 8 and one decile 1 schools. At the time of writing, an additional four interviews with principals from decile 7 and 9 schools were yet to be transcribed. There are currently efforts being made to gain interviews with participants from other socio-economic cohorts in order to present a richer and more diverse contextual picture of experiences.

\section{Significance of conflict management in the education sector}

The education sector is a highly unionised environment with a wide range of legislative requirements, regulations and processes for the delivery of education to New Zealand children. There are conflicting issues and tensions related to the special interdependent relationship between governance by boards of trustees and their management of staff and the principal. This governance structure emerged from reforms in the education sector in 1989 where boards of trustees were established by the Tomorrows Schools policy under the Education Act 1989. Boards became the employer responsible for hiring, discipline and dismissing staff. This governance/management structure treats the principal, who is also a member of the board of trustees, as an employee of the board in the same way the teaching staff are employees of the board of trustees. Each school's board of trustees is a democratically elected group of community representatives who usually have children attending the school.

There has been a raft of tension reported in employment cases across the education sector involving boards of trustees as employers. There are situations where boards of trustees may not have had experience in implementing statutory responsibilities. Relationships between boards, teachers and parents can be intense and require high levels of trust. Board members, who have children attending the school, have the duty to uphold confidentiality and privilege which is balanced with their position as politically elected representatives of the values and views of the school community. Potential conflicts of interest include three sites where power may be particularly contested: parents as governors, principals as managers and chief executives of the school and teachers as staff representatives on boards. Under the circumstances, whether board members and particularly principals can trust board meetings to be places where problems are openly communicated in good faith is a significant question to be answered in the current research, but that issue is not addressed in this paper.

Workplace conflict in the education sector has been identified as particularly vulnerable to escalation due to community involvement in New Zealand schools. In
Lewis $v$ Howick Board of Trustees, Colgan $\mathrm{J}$ the Chief Employment Court Judge, claimed the potential for escalation of conflict in the education sector required caution in regard to procedural legalism. Judge Colgan associated the instigation of formal legal processes by the board of trustees early in the Lewis dispute with escalation of the dispute and conflict involving the whole school community. The commentary of the Chief Employment Court Judge in Lewis reflected earlier secondary research across industry sectors (Waldegrave, 2003; Wyse, 2006) which suggested some lawyers, parties and advocates favoured more adversarial processes than mediation to resolve or settle employment relationship problems in education. Adversarial approaches to negotiation and conflict resolution are deemed to damage trust in relationships and create perceptions of procedural unfairness. Lewicki (2010) identified that repeated positive expectations of good faith negotiation and collaborative conflict management behaviour built, what he termed, 'calculus based' trust over time. The notion of calculus based trust where a number of agreed expectations are met to build a positive psychological contract mirrors the good faith requirements that underpin the ERA 2000.

\section{Discussion: relational trust}

At the time of writing (not withstanding there were still transcriptions to be entered) there were 76 reported conflict events where trust had been identified as a key interest underpinning the employment relationship problem or conflict events. For the purposes of this paper vignettes have been chosen that illustrate dimensions from a body of literature pertaining specifically to relational trust in the education setting. Vignettes reported here also link to the literature on interest based problem solving approaches to conflict management. Following the discussion of favourable outcomes, where relationships have been strengthened or conflict has been resolved, the paper moves to a discussion about outcomes of parental complaints. Participants have reported that settlement of employment relationship problems by severance and competition for management responsibilities can lead to employee disengagement and damage to trust in the primary school workplace.

Collaborative interest based problem solving processes for negotiating day to day issues has facilitated positive change in relationships where there was an explicit focus on good faith open dialogue, reflection and the building of trust. This is significant for schools because, according to Bryk and Schneider (2002), there is a positive correlation between student success and trusting relationships among adults engaged in the school community. They found relational trust was forged through daily social exchanges and the interplay between respect, competence, personal regard for others and integrity. Those qualities were reflected on below by a team leader in a decile 10 school:

I inherited a pretty septic team. The reason the septic culture had occurred was because there had been some relationship breakdowns. There had been a guy in my role who had played good cop bad cop with a woman co-leader, she was the one 
who had to make the hard calls. I wanted it to be more of a problem solving approach. If there is an issue then I go to the person and we talk about their story. For me it is about reassurance and giving people the confidence to know they are trusted enough as professionals that issues are not about them as a person.... my goal this year has been around creating trust in relationships it's gone woosh it's amazing, when people feel safe people are engaged people feel empowered it's all about a collaborative reflective process. I'm reporting comments that staff and management have made about my team...and that is... those... um are the values and the relationships of practice which are very much evident in my team.

Tschannen-Moran and Hoy (2000) described interdependence in a trust relationship required benevolence, reliability, competence, honesty, openness. The advice Tschannen-Moran (2004) offered a principal was to walk the talk of modelling, coaching, managing, negotiating and mediating. We found several examples of a similar approach:

Sometimes a staff member can feel really aggrieved by something - one example might be that two teachers go for the same job in a senior role and one ends up not getting it. So you have to really work with that person. One staff member wrote me a letter and said "I feel this, this and this"- they couldn't talk about it so we sat down; I had the letter in front of me and for the purposes of reflective coaching it was a talking document. (Principal, decile 10 school)

Schuman (2005) focused on consensus building for building trust by allowing individuals to explain their reasoning and intent, focus on interests rather than positions, combine advocacy and inquiry, allow for discussing un-discussable issues, ensure that every person is heard, and promote authentic listening.

I'd uncovered a huge amount of fraud within the school the DP was stealing money and resources and laptops, a whole range of things that'd been going on for yonks. At the Board level we were reenvisioning the school and looking at the mission statement and the vision statement. The motto of the school was when I started, and had been since the school opened to "be honest". So that used to make me laugh, all these rules they had "do not, do not", their vision statement "be honest", all the things they weren't doing. It took us a whole year to develop a new vision statement and our values and where we wanted to head. And I thought this is going to be a joke we're not going to get parents involved in this process compared to high decile schools. But it was the best experience I've ever had. Out of all my schools as a principal I had the most buy in and involvement here. It might have taken a lot of talking and a lot of time but was unbelievable. It was amazing. They came to the focus group meetings and we were talking about it and the conversations went on for ages and they were such sad stories. And they'd be talking about
"My older boy came to the school and principals and the teachers did not care" and telling all these stories which seemed irrelevant to what we were doing but it fed in to what we needed to become (Principal, decile 1 school).

Where there was a need to rebuild trust through authentic dialogue. Redburn's (2009) case study research reported facilitation strategies of active listening and summarising skills, reality testing scenarios for worst and best outcomes were important skills to develop through conflict and communication coaching. Mediators identified successful resolution following early intervention in relationships that involved board members, support staff and teachers.

While in the classroom an aide took direction from the teacher, however the aide was not only an employee of the school but was on the Board of Trustees and a strong contributor to the local community in a number of roles, was well educated and well informed about educational issues. The Teacher was a relative 'new comer' to the community and not involved in as many local groups and committees as the aide. They made several complaints about each other. I met with both parties separately, twice each for about an hour per session. We then met all together for a joint session during which the participants made commitments to each other about their future behaviour which were further negotiated and confirmed by email. The first individual session was an opportunity to get to know the participants and the problem. The second joint session was an opportunity to 'coach' the participants in active listening for the final 'joint' session. The relationship improved and both parties remained employed. (Mediator)

While the above vignettes illustrate resolution of issues involving the rebuilding of relational trust to protect relationships such positive outcomes were not reported in situations that involved competition and financial reward for specific performance. The allocation of units of responsibility was conceptualized by several participants as the beginning of performance pay in the primary education sector and the problem had a negative impact on both trust and subsequent engagement at work when one teacher was not appointed over a colleague.

One of the big things that caused conflict was the allocation of units you know they are rewarding extra effort and there is the principal and the senior management team and they have the ability to allocate those units ...there is supposed to be some level of transparency and the union says you know you have to have priorities in your planning there is no formula or no regulations or rules around who will get these units. In our school the management decides but there is the risk of favourites and subsequent damage to trust. We had one of our teachers who wanted to get into a management position. He wasn't given a position so now he is not doing anything extra in the school such as coaching and sport etc because I guess he 
doesn't feel valued. (Deputy Principal, decile 10 school)

From the data entered to date nearly half of the conflict events reported have involved complaints about teachers. An issue reported across all sets of participants was that parental pressure on Boards of Trustees through competency complaints about teachers was leading to the early negotiation of exit settlement pay-outs. For example:

\begin{abstract}
We had six parents come in and complain about one teacher they had a meeting to see me about the reports because they thought they weren't accurate and they didn't know where their kids were at. We did have in-class support going on for the teacher concerned so we were already in the process before they came in, so we were moving down to competency, and when the six came in, the board chair had a word to the union and said look this is going to go really badly, but we can come to some sort of mediated agreement and well this is what we're prepared to offer, and so ...Everybody saved face. Everybody saves face. Everybody has dignity. It's about everyone having dignity. (Principal, decile 9 school)
\end{abstract}

The idea that these issues can be settled by severance of an employee's position and possibly his/her career has provoked several new questions for this research. It is unknown whether teachers, who exit to a different school, receive professional development or whether there is repetition of the alleged problem when that teacher moves to another school. In settlement negotiation or mediation the reaching of an exit agreement is more important than resolving the cause of the problems. Settlement facilitators take control of the process and this may almost exclusively involve shuttle negotiation. The main goal becomes to settle the dispute or case and it often occurs in the legal rights base context.

Within the education sector there is a strong kind of settlement culture of, if there's a problem you pay something and the teacher moves on. There is not a strong culture of actually addressing problems in the workplace, so there is a sense that you pay someone some money and they go. They get a settlement and also there is a sense that if you do things quickly the teachers council need not become involved and if things get defensive that's sometimes used to put pressure on people to settle. (Employment Lawyer).

All but one principal claimed they had experienced higher levels of parental complaints in schools, though this was also influenced by demographic factors.

I mean if I compare it to when I worked in a low decile school, parents are scared stiff of the teachers in a really big way, they think we are godly things, you know that aren't to be taken on. Decile 10 is the whole other end of the spectrum. You'll get taken on over every little wee thing because their children are extremely precious but on the other hand that's also what I value about working in a school like this because they do all these other positive things with and for their kids

(Principal, decile 10 school).

The observation above was a common theme and several principals claimed evidence that growth in residential gentrification and rising real estate prices corresponded with a rise in parental need for more frequent information and regular contestation about learning and teaching alongside increased expression of parental discontent. The assertion that there is a relationship between wealthy socio-economic areas and high numbers of parental complaint could be the topic of interesting research but it is not the focus of this project.

\section{Conclusion}

This paper has focused on internal conflict management in schools and its impact on relational trust. While favourable processes and outcomes were highlighted there also appeared to be systematic problems. The preliminary findings suggest that the objectives of the ERA 2000 to build productive relationships through promotion of mutual trust built on good faith behavior can be met in situations where an explicit reflective problem solving approach is taken between professional colleagues. However, the interviews also suggest that there are risks and barriers to meeting these objectives where parental complaints escalate. In situations where competition for performance based pay has damaged the psychological contract, productive trusting relationships are at risk. How and under what circumstances relational trust is built through good faith behavior in primary school employment relationships will be sought and answered by analysis of conflict events, context, issues, conflicting interests, relationships and employment relationship problem resolution process in cases where there has been resolution and transformation of employment relationship problems.

Besides contextual barriers, there also appeared to be cultural and mindset issues at play. The findings indicated that there is a culture of seeking 'settlement-at-all-cost' and this approach clearly does not meet the objectives of the ERA 2000. The importance of good faith process and investigation of allegations are issues that have emerged for further analysis from the findings. Additionally, it is notable that the discourse of complaints rather than problems featured strongly in the conflict events reported by the participants. This suggests that a mindset of attributing fault rather than problem solving may have been adopted in some employment relationships between the school community, school management and governors. Building productive relationships through mutual trust may require a problem solving or transformative approach rather than the current framing of problems as complaints.

\section{References}

Antes, J. R., Folger, J. P., \& Della Noce, D. J. (2001). Transforming conflict interactions in the workplace: Documented effects of the USPS 
REDRESS PROGRAM. Hofstra Labour and Employment Law Journal. 18(2): 429-467.

Bingham, L., B. (1997) Mediating Employment Disputes: perceptions of REDRESS at the United States Postal Service. Review of Public Personnel Administration 17 (1), 20-30.

Bingham, L B., \& Chatechere, D. R. (1999). 'Dispute Resolution in Employment: The need for research” in A. E. Eaton and J. H. Keefe (eds) , Industrial Relations Research Association Research Volume: Employment Dispute Resolution and Worker rights in the Changing workplace. Campaign Ill.: Industrial relations Research Association.

Bingham,L. B., Chessmore, G. Moon. Y, \& Napoli LM. (2000). Mediating Employment Disputes at the United States Postal Service: A comparison of in house and outside neutral mediators. Review of Personnel Administration. 20(1): 5-19.

Bingham. L. B. \& Novac, M. C. (2001). Mediations impact on formal discrimination complaint filing: Before and after the REDRESS programme at the United States Postal Service. Review of Personnel Administration. 21(4): 308-331.

Bingham, L. B., Kim, K. \& Raines, S. S. (2002) Exploring the role of representation in employment mediation at the USPS. Ohio State Journal of Dispute Resolution. 17(2): 341-377.

Bingham, L. B. \& Pitts, W. (2002). Highlights of Mediation at Work: Studies of the National REDRESS Evaluation Project. Negotiation Journal, 18(2): 135-146.

Bingham, L. B. (2004). Employment dispute resolution: the case for mediation. Conflict Resolution Quarterly. 22(1-2): 145-174.

Bingham, L. B. (2012). Transformative mediation at the United States Postal Service. International Association for Conflict Management and Wiley Periodicals, Inc.. 5(4): 354-366.

Bowling, D. \& Hoffman, D. (2003). Bringing peace into the room: How the personal qualities of the mediator impact the process of conflict resolution. San Francisco: Jossey-Bass.

Bryk, A. S. \& Schneider, B. (2002). Trust in schools: A core resource for improvement. New York: Russell Sage Foundation

Budd, J. \& Colvin, A. (2008). Improved Metrics for Workplace Dispute Resolution Procedures: Efficiency, Equity and Voice. Industrial Relations. 47(3): 460-479.
Burr, V. (2003). Social Constructionism ( $2^{\text {nd }}$ ed).London: Routledge.

Bush, B. R.A. and Folger, J.P. (2005). The promise of mediation: Responding to conflict through empowerment and recognition ( $2^{\text {nd }}$ ed) JosseyBass: San Francisco.

Cloke, K. and Goldsmith J. (2000) Resolving Personal and Organisational Conflict: stories of transformation and forgiveness San Francisco: Jossey Bass.

Cloke, K. and Goldsmith J. (2000) Resolving conflicts at work: a complete guide for everyone on the job. San Francisco: Jossey-Bass

Cloke, K. (2001) Mediating Dangerously: The frontiers of conflict resolution. San Francisco: Jossey-Bass.

Cloke, K. (2006) The Crossroads of conflict: A journey into the heart of mediation. Canada: Janis publications

Colvin, A. J. S. (2003). The dual transformation of workplace dispute resolution. Industrial Relations. 42(4): 712-735.

Constantino, C.A. and Merchant, C.S. (1996) Designing conflict management systems. San

Cooperrider, D. \& Barrett, F. (1990). Generative Metaphor Intervention: A new approach for working with systems divided by conflict and caught in defensive perception. The Journal of Applied Behavioural Science. 26(2): 219-239.

Creswell, J., W. \& Plano-Clark, V. L. (2007). Designing and Conducting Mixed Methods Research. Thousand Oaks London, UK: Sage.

Crotty, M. (2003). The Foundations of Social Science Research: Meaning and Perspective in the Research Process. ( $2^{\text {nd }}$ ed). London, United Kingdom: Allen \& Unwin.

Cutcher-Gershenfeld, J. and Kochan, T. A. (2004). Taking Stock: Collective Bargaining at the Turn of the Century. Industrial and Labor Relations Review. 58(1):3-26.

Department of Labour. (2002a). The Employment Relations Act: A Summary of the First Eighteen Months (2 October 2000 to 31 March 2002). Wellington, NZ: Department of Labour Employment Relations Service.

Department of Labour. (2002b) The Employment Relations Act: A Summary of the First Two Years 
(2 October 2000 to 30 September 2002). Wellington, NZ: Department of Labour.

Donais, B. (2006) Workplaces that work: A guide to conflict management in union and non-union work environments. Ontario: Canadian Law Book, Division of the Cartwright Group.

Dunlop, J. T. \& Zac, A. (1997). Employment Dispute Resolution Mediation and Arbitration of Employment Disputes. San Francisco: Jossey-Bass Inc.

Ewing, D. W. (1989) Justice on the job: Resolving grievances in the Non Union Workplace. Boston: Harvard Business School Press.

Felstiner, W. L. F., Abel, R. L. \& Sarat, A. (1981) Emergence and transformation of Disputes, Naming, Blaming, Claiming. Law \& Society Review. 15(3-4): 631-654.

Fisher, R. \& Ury, W. (1981). Getting to Yes: Negotiating an Agreement without giving in. Houghton Miflin,

Fueille, P., Chatchere, D.R. \& Delaney, J. T. (1992). The individual pursuit of organisational justice: grievance procedures in non union workplaces. Research in Personnel and Human resources management. 10: 187-232.

Guba, E. G. \& Lincoln, Y. S. (1994). Handbook of Qualitative Research. Thousand Oaks, CA, US: Sage Publications.

Guest, D. E. (2004). The psychology of the Employment Relationship: An analysis based on the psychological contract. Applied Psychology: an International Review, 53(4): 541- 555.

Jameson, J. K. (2001). Employee perceptions of the availability and use of interest based, rights based and power based conflict management strategies. Conflict Resolution Quarterly. 19(2): 163-195.

King, N. \& Horrocks, C. (2010). Interviews in Qualitative Research. Los Angeles, USA: Sage.

Lewicki, R. J., Saunders, D. M. \& Minton, J.W. (1999) Negotiation ( $3^{\text {rd }}$ ed). Boston: McGraw-Hill.

Lewin, D. (1987). Dispute Resolution in the Non-Union firm: a Theoretical and Empirical Analysis. Journal of Conflict Resolution. 31(3): 465-502.

Lewin, D. (2004). 'Dispute management in non-union organisations'. In S. Estreicher and D. Sherwyn (eds.), Alternative Dispute Management in the Employment Arena. New York: Kluwer, pp. 379403.
Lipsky D., B. \& Seeber, R.L. (2003). The Social Contract and Dispute Management: the transformation of the social contract and dispute management in the US workplace and the emergence of new strategies of dispute management. International Employment Relations Review. 9: 87-109.

Mayer, B. S. (2004). Beyond Neutrality: Confronting the crisis in conflict resolution. San Francisco: JosseyBass.

McCabe, D. M. (1988). Corporate Non Union Complaint Procedures and Systems. New York: Praeger

McAndrew, I. (2010). 'The Employment Institutions'. In Rasmussen, E. (ed), Employment Relations in New Zealand $\left(2^{\text {nd }}\right.$ ed). Auckland, New Zealand: Auckland University Press, pp. 74-93.

McDermot, E. P. (1995). Survey of 92 Key Companies: Using ADR to settle Employment Disputes. Dispute Resolution Journal. 50(1): 8-13.

McDermott Miller Limited. (2007). Social \& Economic Costs and Benefits of Employment Relationship Problems: Technical Report. Wellington, Department of Labour, August 2007.

Osterman, P. (1994). How common is workplace transformation and who adopts it? Industrial and Labour Relations Review. 47: 173-88.

Ostrom, E. (2006). Understanding Institutional Diversity. Princeton: Princeton University Press.

Redburn, M. (2009). Developing relational trust in schools through a consensus process, International. Journal of Educational Leadership Preparation (IJELP) v10.1.

Roche, W. K. \& Teague, P. (2011).Firms and Innovative Conflict Management Systems in Ireland. British Journal of Industrial Relations. 49(3): 436-459.

Rousseau, D. \& Tijoriwala, S. (1998). Assessing Psychological Contracts: Issues, Alternatives and Measures. Journal of Organizational Behaviour, 19: 679-696.

Rousseau, D. (2004). Mutuality and reciprocity in psychological contracts of employees and employers. Journal of Applied Psychology. 89: 5272.

Schuman, S. (Ed). (2005). The IAF handbook of group facilitation: Best practices from the leading organization in facilitation. San Francisco: JosseyBass. 
Shulruf, B., Woodhams, B., Howard, C., Johri, R. \& Yee, B. (2009). Grievance Gravy Train Picking up Speed: Myths and Reality around Employment Disputes in New Zealand. Journal of Industrial Relations. 52(2): 245-260.

Stone, K. (2004). From Digits to Widgets: Employment Regulation for the changing Workplace. New York: Cambridge University Press.

Tillet, G. \& French, B. (2010). Resolving Conflict (4 ${ }^{\text {th }}$ ed). Melbourne: Oxford University Press.

Tschannen-Moran, M. \& Hoy, W. K. (2000). A multidisciplinary analysis of the nature, meaning, and measurement of trust. Review of Educational Research. 70(4): 547-593.

Tschannen-Moran, M. (2004). Principals' sense of efficacy: assessing a promising construct. Journal of Educational Administration. 42(5): 573.

Ury, W. L., Brett, J. M. \& Goldberg, S. B. (1988). Getting disputes resolved: Designing systems to cut the costs of conflict. San Francisco: JosseyBass.

Waldergrave, T. Anderson, D. \& Wong, K. (2003). Evaluation of the Short Term Impacts of the Employment Relations Act 2000. Wellington: Department of Labour

Walker, B. (2009). For Better or For Worse: Employment Relationship Problems under the Employment Relations Act 2000. Unpublished PhD. Thesis. Christchurch: Canterbury University.

Walker, B. \& Hamilton, R. (2010). Grievance process: research rhetoric and directions for New Zealand. New Zealand Journal of Employment Relations. 34(3): 43-64.

Walton, R. E, Cutcher-Gershenfeld, J. E. \& McKersie, R. B. (2000). Strategic Negotiations: a theory of change in labour management relations. Ithaca: ILR Press- Cornell University Press.

Wilson, Hon M. (2000). 'Free, fast and fair - a new Mediation Service for New Zealand businesses and employees', media release, 13 July 2000.

Winslade J. \& Monk, G (2008). Practicing narrative mediation: Loosening the Grip of Conflict. San Francisco: Jossey-Bass.

Woodhams, B. (2007). Employment relationship problems cost benefits and choices. Wellington: Department of Labour, August 2007.
Wyse, K. (2003). The Employment Relations Act 2000: A failed attempt? Special Topic Department of Management \& Employment Relations, University of Auckland. 